ity to the olfactory stimulus 1-octanol // PLoS One. 2010. Vol. 5. DOI: 10.1371/journal.pone.0009487.

22. Hoffmann A.A., Sørensen J.G., Loeschke V. Adaptation of Drosophila to temperature extremes: bringing together quantitative and molecular approaches // J. Therm. Biol. 2003. Vol. 28. P. 175-216.

23. Kalinnikova T.B., Kolsanova R.R., Shagidullin R.R., Osipova E.B., Gaynutdinov M.Kh. On the role of gene of SER-4 serotonin receptor in thermotolerance of Caenorhabditis elegans behavior // Russian J. Genetics. 2013. Vol. 49. P. 363-366.

24. Suo S., Ishiura S. Dopamine modulates acetylcholine release via octopamine and CREB signaling in Caenorhabditis elegans // PLoS ONE. 2013. Vol. 8. DOI: 10.1371/journal.pone.0072578.

\title{
THE POSSIBLE ROLE OF DOPAMINE RECEPTORS DOP-1 AND DOP-3 IN BEHAVIOR THERMOTOLERANCE REGULATION OF CAENORHABDITIS ELEGANS MAUPAS
} (C) 2018

Kalinnikova Tatiana Borisovna, candidate of biological sciences, head of the Laboratory of Experimental Ecology Kolsanova Rufina Rifkatovna, candidate of biological sciences, researcher of the Laboratory of Experimental Ecology

Belova Evgenia Borisovna, junior researcher of the Laboratory of Experimental Ecology Research Institute for Problems of Ecology and Mineral Wealth Use of Tatarstan Academy of Sciences (Kazan, Russian Federation)

Khakimova Dilyara Makhmutrievna, candidate of medical sciences, senior lecturer of the Department of Morphology and General Pathology Kazan (Volga Region) Federal University (Kazan, Russian Federation)

Gainutdinov Marat Khamitovich, doctor of biological sciences, professor, senior researcher of the Laboratory of Experimental Ecology

Shagidullin Rifgat Roaldovich, doctor of chemical sciences, corresponding member of the Tatarstan Academy of Sciences, director Research Institute for Problems of Ecology and Mineral Wealth Use of Tatarstan Academy of Sciences (Kazan, Russian Federation)

Abstract. The paper investigates dopamine influence on the tolerance of swimming, induced by mechanical stimulus, to the temperature of $36^{\circ} \mathrm{C}$ during the experiments with nematodes of wild type strain $\mathrm{N} 2$ and mutant strains LX636 (dop-1(vs101)) and LX703 (dop-3(vs106)) with null-mutations of genes of dopamine receptors DOP-1 and DOP-3. The authors have shown that dopamine in concentrations $0,5-1,0 \mathrm{mM}$ increased the behavior thermotolerance of $C$. elegans while in concentrations 7,5-15,0 dopamine caused its decrease. Null-mutation of dopamine receptor gene $d o p-3$ prevented the decrease of $C$. elegans thermotolerance by dopamine. On the contrary, null-mutation of dopamine receptor gene dop- 1 caused significant rise in sensitivity of behavior thermotolerance to dopamine. In connection with well-known conceptions assuming that the reason of heat damage of $C$. elegans behavior is acetylcholine deficiency due to inhibition of its secretion by hyperthermia, the dopamine influence on behavior thermotolerance can be accounted for the dopamine influence on acetylcholine secretion by motor neurons. It is known that in C. elegans motor neurons the coexpression of genes of receptors DOP-1 and DOP-3 takes place. Activation of these receptors in turn causes opposite changes in dopamine secretion.

Keywords: soil nematode Caenorhabditis elegans; swimming thermotolerance induced by mechanical stimulus; dopamine; genes of dopamine receptors DOP-1 and DOP-3; null-mutations of dopamine receptors genes dop-1 and dop-3; acetylcholine deficiency in organism; regulation of organism thermotolerance by dopamine.

\section{ОЦЕНКА ЭКОЛОГИЧЕСКОГО СТАТУСА МИКРОБНОЙ ПОПУЛЯЦИИ ИЗ ОСНОВНОГО САПРОТРОФНОГО МИКРОБНОГО ПУЛА ДЕРНОВО-ПОДЗОЛИСТОЙ ПОЧВЫ ПРИ БИОХИМИЧЕСКОЙ ДЕСТРУКЦИИ ДИАТОМИТА ИНЗЕНСКОГО МЕСТОРОЖДЕНИЯ В УСЛОВИЯХ ЛАБОРАТОРНОГО ЭКСПЕРИМЕНТА}

Козлов Андрей Владимирович, кандидат биологических наук, доцент кафедры экологического образования и рационального природопользования Нижегородский государственный педагогический университет имени Козьмы Минина (2. Нижний Новгород, Российская Федерация)

Куликова Алевтина Христофоровна, доктор сельскохозяйственных наук, заведующий кафедрой почвоведения, агрохимии и агроэкологии

Ульяновский государственный аграрный университет имени П.А. Столыпина (2. Ульяновск, Российская Федеращия)

Уромова Ирина Павловна, доктор сельскохозяйственных наук, профессор кафедры биологии, химии и биолого-химического образования Нижегородский государственный педагогический университет имени Козьмы Минина (2. Нижний Новгород, Российская Федерация)

Аннотациия. В настоящей статье рассматривается реакция сапротрофной и аммонифицирующей микробных популяций, выделенных из дерново-подзолистой легкосуглинистой почвы Нижегородской области, на 

вещество диатомита Инзенского месторождения, на основе чего впоследствии оценивается экологический статус данных микроорганизмов по отношению к изучаемой высококремнистой породе. В исследованиях использовались 7-дневные накопительные культуры общих сапротрофных и аммонифицирующих бактерий. Живые клетки выделялись из дерново-подзолистой почвы, отобранной с поля ООО «Элитхоз» Борского района по общепринятым в микробиологической биотехнологии правилам. Результатом исследований явилась 30-дневная динамика системы «порода-культура» в части изменения численности живых клеток и протеолитической ферментативной активности бактериальных суспензии при биохимической деградации вещества диатомита. Описанная реакция микробных комплексов в виде положительной динамики численности и протеазной активности свидетельствует о прямом деструкционном взаимодействии бактериальных культур с диатомовой породой, что, в свою очередь, может предполагать их активную реакцию с данной породой и органическим веществом самой почвы с последующим высвобождением в почвенный раствор различных питательных элементов и в целом - стабилизацию бактериальных L-стратегов в общем экологическом статусе микробиоценоза почвы.

Ключевые слова: диатомовая порода Инзенского месторождения; дерново-подзолистая легкосуглинистая почва; бактериальные L-стратеги; общие почвообитающие сапротрофы; аммонификаторы; система «породакультура»; жизнеспособность бактериальной культуры; протеолитическая ферментативная активность; устойчивость экологического статуса почвенного микробиоценоза.

\section{Введение}

Изучение состояния эколого-трофического статуса почвенно-биотического комплекса (ПБК) в условиях воздействия на почвы со стороны различных агротехнических приемов и применения удобрений является ключевой задачей при решении вопросов о степени и направленности трансформации вещества в почвенном теле. В том числе и в условиях внесения в почвы нетрадиционных удобрительных веществ, которым в настоящее время уделяется особое внимание. В частности, к таковым относят природные высококремнистые породы [1-3], которые обладают самыми разными положительными свойствами, но при этом их взаимодействие с твердой фазой почвы и особенно с ее «живой» составляющей пока остается наименее изученным аспектом. Так, было установлено, что некоторые из таких материалов способны изменять направленность трансформации как относительно простых органических веществ [4], так и сложных предгумусовых матриц [5; 6]. В данном случае весьма значимым остается выявление потенциальной способности сапротрофных микроорганизмов к деструкции вещества кремнийсодержащих материалов и, как следствие, отслеживание изменений в экологическом статусе данной микробиоты.

\section{Цель исследования}

Целью настоящего исследования явилась оценка потенциальных изменений в бактериальной популяции основных сапротрофов, выделенных из дерновоподзолистой легкосуглинистой почвы Нижегородской области, при биохимической деструкции диатомовой породы Инзенского месторождения.

\section{Объекты исследования}

Объектами исследования явились диатомит Инзенского месторождения (Ульяновская обл.) и две группы сапротрофных микроорганизмов, выделенных из дерново-подзолистой легкосуглинистой почвы.

Диатомиты представляют собой аморфные кремнийсодержащие породы органического генеза, сформированные из остатков диатомовых водорослей. Диатомиты обладают рядом различных свойств, питательность и каталитическая способность из которых являются наиболее значимыми с точки зрения агрономического почвоведения. Некоторые свойства Инзенской диатомитовой породы отражены в таблице 1 в виде химического состава [7].

Таблица 1 - Обобщенный химический состав диатомита Инзенского месторождения

\begin{tabular}{|c|c|c|c|c|c|c|}
\hline \multirow{2}{*}{ Порода } & \multirow{2}{*}{ ИЕ* } & \multicolumn{5}{|c|}{ Элемент в оксидной форме (на абс.-сух. вещество) } \\
\hline & & $\mathrm{SiO}_{2}$ & $\mathrm{P}_{2} \mathrm{O}_{5}$ & $\mathrm{~K}_{2} \mathrm{O}$ & $\mathrm{CaO}$ & $\mathrm{MgO}$ \\
\hline $\begin{array}{l}\text { Диатомит } \\
\text { - валовая форма, \% } \\
\text { - подвижная форма, мг/кг }\end{array}$ & 80 & $\begin{array}{c}83,1 \\
12200\end{array}$ & $\begin{array}{c}0,05 \\
37\end{array}$ & $\begin{array}{l}1,25 \\
350\end{array}$ & $\begin{array}{c}0,52 \\
10\end{array}$ & $\begin{array}{c}0,48 \\
39\end{array}$ \\
\hline
\end{tabular}

Примечание. *- ионообменная емкость, мг-экв./100 г.

\section{Материалы и методика исследований}

Биохимическое взаимодействие диатомита с бактериальными культурами сапротрофных групп микроорганизмов изучали в серии моделируемых лабораторных экспериментов, проведенных в 2017 году на базе научно-образовательного центра «Биотехнология» и лабораторного комплекса «Эколого-аналитическая лаборатория мониторинга и защиты окружающей среды» Мининского университета.

Накопительную культуру общего комплекса сапротрофных бактерий получали путем засева жидкого варианта стерильного глюкозо-пептонно-дрожжевого агара (ГПДА с разбавлением рецептурного количества агар-агара в 10 раз), а культуру аммонифи- цирующих бактерий - жидкого варианта стерильного мясопептонного агара (МПА) навеской подготовленной почвы и культивирования бактериальных биомасс в термостате в течение 7 суток при температуре $+25 \ldots+27^{\circ} \mathrm{C}[8-10]$.

Затем производили засев испытуемых пород полученными бактериальными комплексами. Опыты ставили в стерильных конических колбах на 100 мл, в которые асептически помещали по 40 мл селективной жидкой питательной среды и по 1,000 $\pm 0,001$ г высушенной кремнийсодержащей породы, после чего полученную систему асептически засевали по 10 мл суспензии 7-ми суточной накопительной культуры выращенных бактериальных комплексов. 
Засеянные колбы помещали в термостат и культивировали при $+25 \ldots+27^{\circ} \mathrm{C}$ в течение 30 суток; 2 раза в сутки содержимое колб встряхивали в течение 1го часа на шейкере. Через определенные интервалы времени (на $1,3,5,7,10,12,15,20,25$ и 30 день культивирования) производили определения микробиологических и биохимических показателей содержимого колб. В системе «порода-культура» определяли численность живых клеток и протеазную ферментативную активность; повторность в опытах четырехкратная.

Определение протеазной активности бактериальной суспензии обеих питательных сред проводили по прописям определения ферментативной активности почвы с переложением методик на чистую биомассу бактерий (культуральную жидкость) без гомогенизирования бактериальных клеток классическим нингидриновым спектрофотометрическим методом по Галстяну и Арутюнян [11].

Численность бактериальных комплексов в культуральных жидкостях систем «порода-культура» определяли с помощью обычной световой и люминесцентной микроскопии с акридином оранжевым [12] на микроскопе «БиоТех-330-LED2-Tr».

Математическую обработку полученных данных проводили методом вариационного анализа по Б.А. Доспехову [13] с использованием программного пакета Microsoft Office Excel.

\section{Результаты исследований и их обсуждение}

Экологический статус сапротрофного микробного пула в почве заключается в L-отборе (или отборе неблагоприятных условий), который проявляется в виде массового размножения популяций микроорганизмов, обычно пребывающих в незначительных количествах, но способных резко увеличивать свою плотность населения при сезонных опадах траво- и древостоя, а также при внесении в почву различных органических удобрений. L-стратеги отличаются устойчивостью к стрессовым ситуациям и, как следствие, способностью к перенесению экстремальных условий существования. К таким микроорганизмам относится вся гидролитическая микрофлора, способная выделять аналогичные гидролазные экзоферменты [14].

Поэтому совместная оценка численности вышеупомянутых групп микробиоценоза из категории Lстратегов и гидролитической ферментативной активности почвы являются наиболее предпочтительными в изучении влияния последствий от применения удобрительных веществ на процессы преобразования органического вещества почвы и, в частности, при оценке дальнейшей значимости использования диатомита в качестве мелиоранта и микробиологического стабилизатора.

Данные рисунка 1 отражают состояние и динамику численности общих сапротрофов и аммонификаторов, выделенных из дерново-подзолистой почвы, при взаимодействии с диатомовой породой.

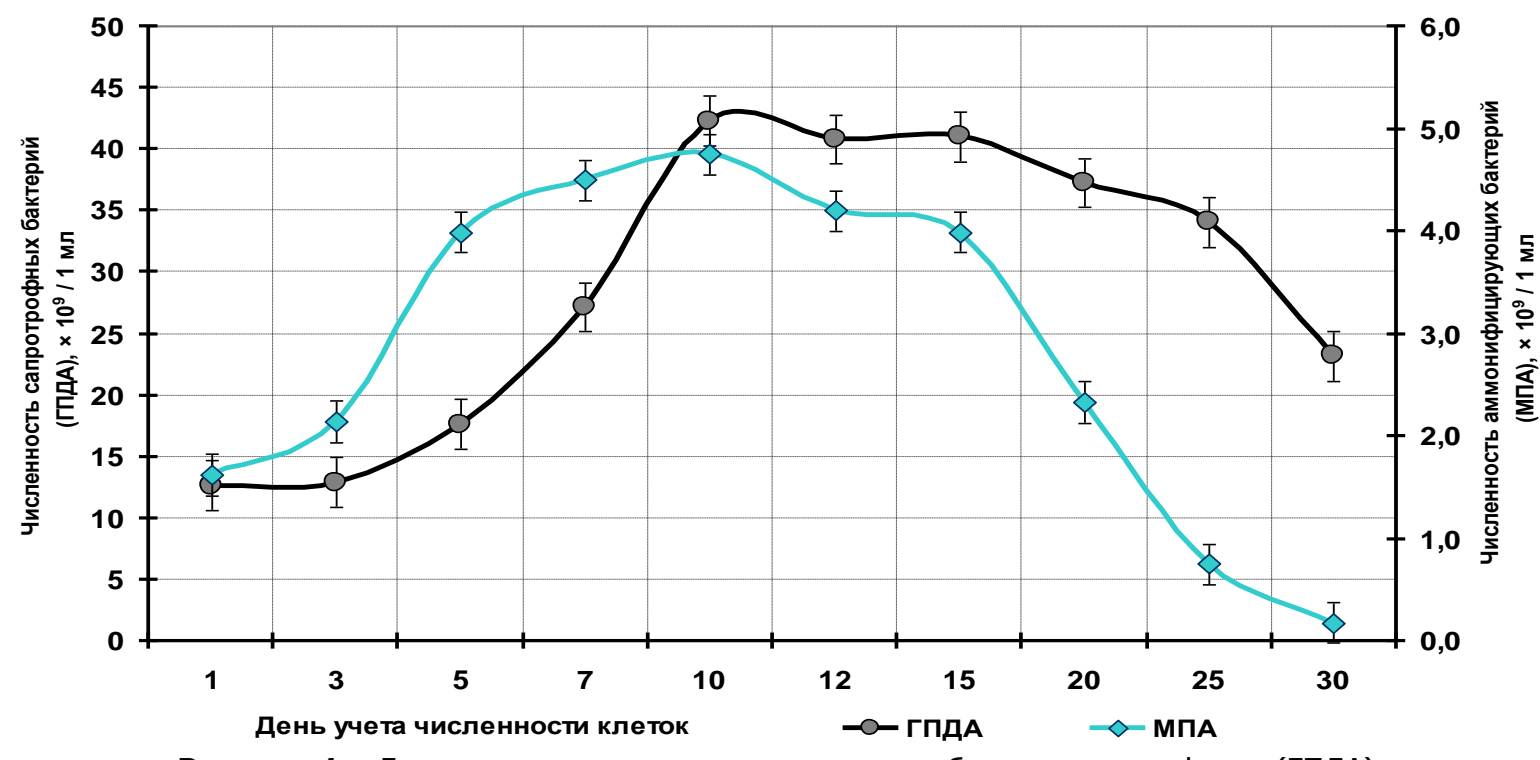

Рисунок 1 - Динамика численности живых клеток общего сапротрофного (ГПДА)

и аммонифицирующего (МПА) бактериальных комплексов при биохимической деградации диатомита

Было выявлено, что чистая микробная биомасса обеих рассматриваемых культур способна расти и изменяться в численности на среде, обогащенной диатомовой породой. Пик наибольшего количества живых клеток пришелся на 10-й день культивирования систем «порода-культура»: $36,30 \times 10^{9} / 1$ мл общих сапротрофов и $4,75 \times 10^{9} / 1$ мл аммонифицирующих бактерий. Далее шел спад числа жизнеспособных клеток, который несколько различался по культурам. Так, если аммонификаторы достаточно резко погибали и на 30-й день культивирования достигли в числе $0,18 \times 10^{9} / 1$ мл, то общие сапротрофы вторую половину экспозиции культивирования сохраняли свое количество, только лишь к концу сократившись до $23,17 \times 10^{9} / 1$ мл.

Поскольку в структуру общих сапротрофов, выделенных из почвы на ГПДА, входят как непосредственно бактерии-гидролитики, так и копиотрофы и олиготрофы [14], можно предположить, что именно за счет бактериального разнообразия весь комплекс сохраняет свою устойчивость более продолжительное время.

Однако, несмотря на столь отзывчивую реакцию рассматриваемых групп бактерий на вещество диатомовой породы, активность их протеолитических ферментов в целом оказалась существенно низкой по уровню (рис. 2). 


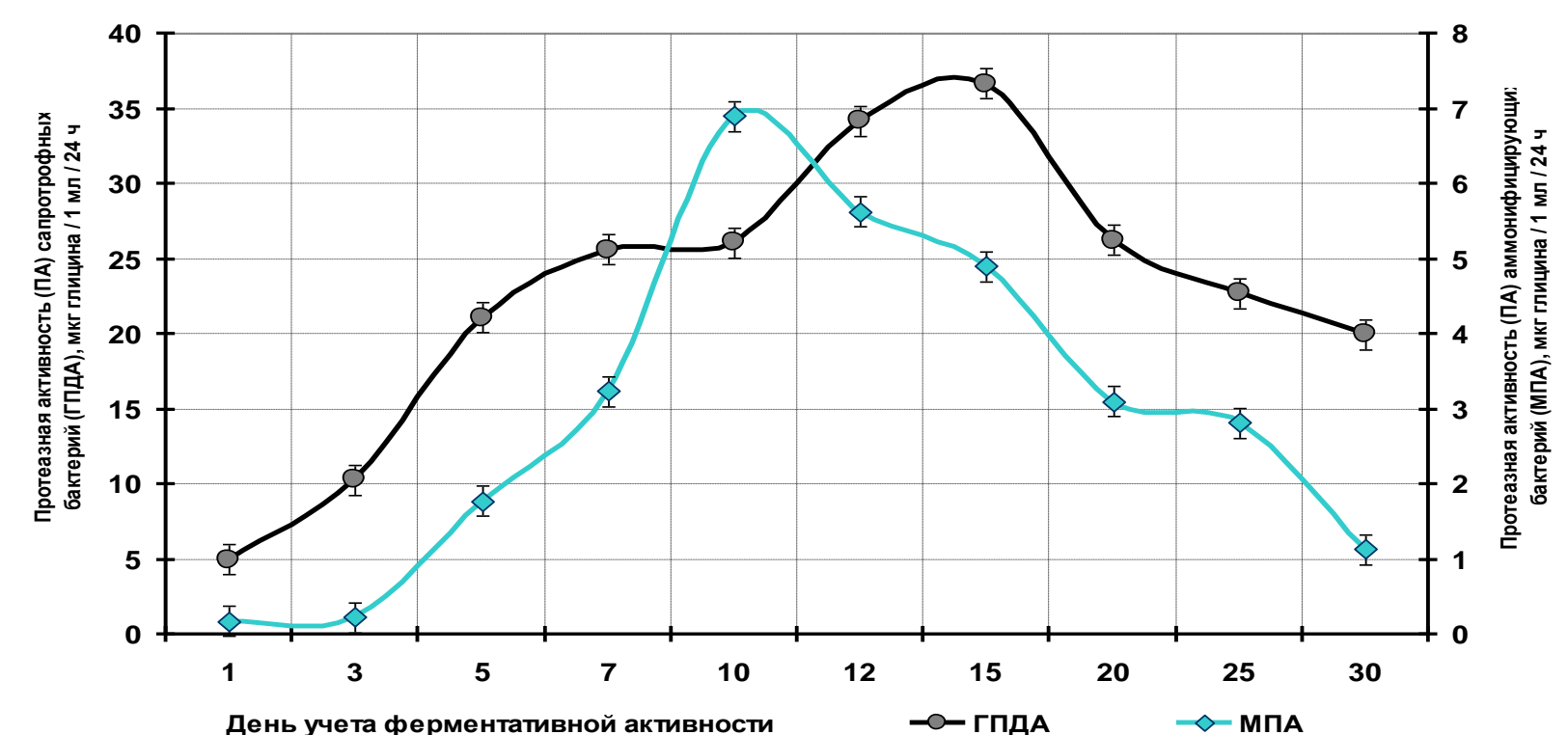

Рисунок 2 - Динамика протеазной ферментативной активности бактериальных суспензий сапротрофного (ГПДА) и аммонифицирующего (МПА) комплексов при биохимической деградации диатомита

Аналогично численности жизнеспособных клеток пик протеазной активности также пришелся на 1015-й дни и также в существенной разнице различался между культуральными жидкостями: до 36,66 мкг глицина/1 мл/24 ч. по ГПДА-культуре и до 6,90 мкг глицина/1 мл/24 ч. по МПА-культуре.

Спад ферментативной активности при деградации диатомита происходил относительно степенно в условиях его взаимодействия с общим сапротрофным комплексом (до 19,97 мкг глицина/1 мл/24 ч.) и более резко - в системе «порода-культура» с аммонифицирующей бактериальной суспензией (до 1,13 мкг глицина/1 мл/24 ч.).

По-видимому, наличие положительной реакции в жизнеспособности сапротрофных бактерий и их ферментативной активности объясняется питательными и каталитическими свойствами диатомита, которые, в свою очередь, активизируют процессы минерализации органического вещества питательных сред наряду с материалом породы [2; 5].

\section{Выводы}

В результате проведенных исследований была установлена положительная реакция сапротрофного микробного пула, выделенного из дерново-подзолистой почвы Нижегородской области, на вещество диатомита Инзенского месторождения. На основе полученных данных можно предполагать, что экологический статус рассмотренных бактериальных популяций в самой почве активизируется при совместном взаимодействии диатомовой породы и почвенного органического вещества, что приведет к повышению устойчивости всего микробиоценоза L-стратегии выживания как начальной стадии микробиологической переработки органических компонентов в почвенном теле.

\section{Список литературы:}

1. Бочарникова Е.А., Матыченков В.В., Матыченков И.В. Кремниевые удобрения и мелиоранты: история изучения, теория и практика применения // Агрохимия. 2011. № 7. С. 84-96.

2. Козлов А.В., Куликова А.Х., Яшин Е.А. Роль и значение кремния и кремнийсодержащих веществ в агроэкосистемах // Вестник Мининского университета. 2015. № 2 (10). С. 23.

3. Матыченков В.В., Бочарникова Е.А., Аммосова Я.М. Влияние кремниевых удобрений на растения и почву // Агрохимия. 2002. № 2. С. 86-93.

4. Козлов А.В., Куликова А.Х. Влияние высококремнистых пород на структуру, численность и ферментативную активность целлюлозосапротрофного микробного пула дерново-подзолистой почвы в условиях выращивания озимой пшеницы и картофеля // Вестник Ульяновской государственной сельскохозяйственной академии. 2016. № 1 (33). С. 56-65.

5. Козлов А.В., Куликова А.Х., Уромова И.П. Влияние высококремнистых пород (диатомита, цеолита и бентонитовой глины) на активность олиготрофного и автохтонного микробного пула дерново-подзолистой почвы // Вестник Томского государственного университета. Серия: Биология. 2017. № 4 (40). C. 44-65.

6. Матыченков В.В. Роль подвижных соединений кремния в растениях и в системе почва-растение: автореф. дис. ... д-ра биол. наук. Пущино, 2008. 34 с.

7. Дистанов У.Г. Минеральное сырье. Опал-кристобалитовые породы: справочник. М.: Геоинформарк, 1998. 27 с.

8. Практикум по микробиологии / под ред. А.И. Нетрусова. М.: Изд. Центр «Академия», 2005. $608 \mathrm{c}$.

9. Безбородов А.М., Квеситадзе Г.И. Микробиологический синтез. СПб.: Проспект Науки, 2011. $144 \mathrm{c}$.

10. Грачева И.М., Иванова Л.А. Биотехнология биологически активных веществ. М.: Элевар, 2006. $453 \mathrm{c}$.

11. Хазиев Ф.Х. Методы почвенной энзимологии. М.: Наука, 2005. 252 с.

12. Лысак Л.В., Добровольская Т.Г., Скворцова И.Н. Методы оценки бактериального разнообразия почв и идентификации почвенных бактерий. М.: МАКС Пресс, 2003. 120 с.

13. Доспехов Б.А. Методика полевого опыта (с основами статистической обработки результатов исследований). М.: ИД Альянс, 2011. 352 с. 
14. Добровольская Т.Г., Головченко А.В., Лы- териальных и актиномицетных комплексов торфясак Л.В., Зенова Г.М. Физикохимия и биология тор- ных почв. Томск: Издательство Томского ГПУ, 2010. фа. Методы оценки численности и разнообразия бак- 97 с.

\section{ECOLOGICAL STATUS ASSESSMENT OF MICROBIC POPULATION FROM CESPITOSE-PODSOLIC SOIL BASIC SAPROTHROPHIC MICROBIC POOL AT THE INZENSKY FIELD DIATOMITE BIOCHEMICAL DESTRUCTION}

(C) 2018

Kozlov Andrey Vladimirovich, candidate of biological sciences, associate professor of Ecological Education and Rational Environmental Management Department Minin Nizhny Novgorod State Pedagogical University (Nizhny Novgorod, Russian Federation)

Kulikova Alevtina Hristoforovna, doctor of agricultural sciences, head of Soil Science, Agrochemistry and Agroecology Department Ulyanovsk State Agrarian University named after P.A. Stolypin (Ulyanovsk, Russian Federation)

Uromova Irina Pavlovna, doctor of agricultural sciences, professor of Biology, Chemistry and Biological and Chemical Education Department Minin Nizhny Novgorod State Pedagogical University (Nizhny Novgorod, Russian Federation)

Abstract. The following paper considers reaction of the saprothrophic and ammoniphycal microbic populations, allocated from the cespitose-podsolic sandy loamy soil of the Nizhny Novgorod Region, to the Inzensky field diatomite substance. On this basis the ecological status of these microorganisms in relation to the studied high-siliceous breed is estimated subsequently. 7-day accumulative cultures of general saprothrophic and ammoniphycal bacteria were used in the study. Living cells were emitted from the cespitose and podsolic soil selected from the Borsky district field «Elitkhoz» by the standard rules in microbiological biotechnology. The result of the research was 30-day dynamics of the breed culture system regarding change of living cells number and proteolytic enzymatic activity of bacterial suspension at biochemical degradation of diatomite substance. The described reaction of microbic complexes in the form of positive dynamics of number and protease activity demonstrates direct destruction interaction of bacterial cultures with diatomite breed that, in turn, can assume their active reaction with this breed and organic substance of the soil with the subsequent release in soil solution of various nutritious elements and in general - stabilization of bacterial L-strategists in the general ecological status of soil microbiocenosis.

Keywords: diatomite breed of Inzensky field; cespitose and podsolic sandy loam soil; bacterial L-strategists; general soil dwelling saprothrophic; ammoniphycal; breed culture system; viability of bacterial culture; proteolytic enzymatic activity; stability of soil microbiocenosis ecological status.

\section{НОВЫЙ МЕТОДИЧЕСКИЙ ПОДХОД К ОЦЕНКЕ МЕХАНИЧЕСКОЙ УСТОЙЧИВОСТИ ЗЕЛЁНЫХ НАСАЖДЕНИЙ В ГОРОДСКОЙ СРЕДЕ}

(C) 2018

Корниенко Владимир Олегович, старший преподаватель кафедры биофизики

Донеикий национальный университет (г. Донеик, Донецкая Народная Республика)

Приходько Светлана Анатольевна, кандидат биологических наук, старший научный сотрудник, директор Донецкий ботанический сад (2. Донецк, Донецкая Народная Республика)

Аннотация. Наибольший прессинг негативных экзогенных факторов испытывают деревья, произрастающие в городской среде, и как следствие многие породы древесных растений достигают критического возраста и являются аварийными. Комплексный подход к оценке состояния древесных насаждений в условиях техногенной нагрузки с использованием визуальных, инструментальных, биомеханических и других методов позволит своевременно и достоверно выявлять потенциально аварийные растения. Для достижения этой цели нами была разработан новый методический подход к определению степени аварийности деревьев в населённых пунктах на основе учёта оценки механической устойчивости древесных растений и данных современных инструментальных методов исследований, которые могут быть использованы службами, осуществляющими мониторинг состояния и уход за зелёными насаждениями. Основными параметрами служат: возраст, диаметр основания, диаметр на высоте, обхват ствола у основания, обхват ствола на высоте 1,3 м, высота дерева, угол наклона ствола, балл жизненного состояния по Савельевой, морфологические повреждения ствола, описание архитектоники кроны, наличие морфогенетических и экзогенных повреждений листовой пластинки, заселённость ствола вредителями, наличие дупел, ветровая особенность и нагруженность данного участка местности, режим посещения территории (рекреационная нагрузка), направление возможного падения, длина участка здоровой древесины на керне, процент ядровой гнили, модуль упругости древесины, плотность древесины, отношение биомассы к критической массе, механическая устойчивость к статическим и динамическим нагрузкам согласно расчётам по биомеханике. В статье на примере модельного дерева платана кленолистного продемонстрирована возможность использования такого подхода в практической работе.

Ключевые слова: аварийные деревья; механическая устойчивость; визуальная диагностика; модуль упругости; инструментальная диагностика; шкала аварийности; критическая нагрузка; антропогенное влияние; приростной бурав; Platanus acerifolia (Aiton) Willd.; статическая нагрузка; динамический фактор; ветер. 